\title{
POST-OPERATIVE APNOEA CAUSED BY BREATH-HOLDING SPELLS
}

\author{
Charles H. Hubgert
}

\section{INTRODUCTION}

A TWO-AND-A-HALF-YEAR-OLD BOY with a history of breath-holding spells became apnoeic and cyanotic after emergence from anaesthesia. Brief ventilation with oxygen was the only therapy required for the breath-holding spell. Breathholding as a cause of post-operative apnoea was not found in a review of the recent literature. The pathophysiology of breath-holding and a differential diagnosis of postoperative apnoeas are discussed.

\section{CAse Report}

A two-and-a-half-year-old white male underwent operation for right ureteroneocystostomy. There was a history of breath-holding spells beginning at the age of eighteen months. Preoperative evaluation revealed a weight of $14 \mathrm{~kg}$, haematocrit 35 per cent, normal electrolytes and urinalysis, and an estimated blood volume of 1050 $\mathrm{ml}$. Intramuscular hydroxyzine $25 \mathrm{mg}$ and atropine $0.2 \mathrm{mg}$ were given pre-operatively. Mask induction of anaesthesia using halothane, nitrous oxide and oxygen was followed by pancuronium $1.5 \mathrm{mg}$ intravenously for tracheal intubation. Anaesthesia was maintained with morphine sulfate $6 \mathrm{mg}$, nitrous oxide-oxygen (2:1), and hyperventilation. During the two-and-one-half-hour procedure pancuronium $1.0 \mathrm{mg}$ was given, $0.5 \mathrm{mg}$ being given 45 minustes before the end of the operation. This relaxant was ad equately reversed by atropine $0.3 \mathrm{mg}$ and neostigmine $0.9 \mathrm{mg}$. Blood loss of $160 \mathrm{ml}$ was replaced by $250 \mathrm{ml}$ of quarterstrength saline in five per cent dextrose and 600 $\mathrm{ml}$ of lactated Ringer's solution. After the nitrous oxide was discontinued he became responsive; ventilated adequately and helped with a smooth extubation. While being transferred to the recovery room, he became apnoeic and cyanotic. After ventilation by mask with 100 per cent oxygen for approximately one to one and a half minutes, he resumed spontaneous respirations and was easily

Charles H. Hubbert, M.D., Pediatric Anesthesiology, Le Bonheur Children's Hospital, 848 Adams Ave., Memphis, Tennessee 38103, U.S.A.

Canad. Anaesth. Soc. J., vol. 25, no. 2, March 1978 arousable. An uneventful post-operative course allowed discharge on the sixth day.

\section{Discussion}

Breath-holding spells ${ }^{1-3}$ are non-epileptic episodes of unconsciousness precipitated by fear, rage, weeping, pain, or frustration occurring primarily in children under six years of age. These spells are initiated by a spontaneous Weber-Valsalva Manoeuver in which the child holds his breath and tries to exhale against a closed glottis. The resulting high intrathoracic pressure forces blood out of the vena cavae away from the heart, reducing venous return. The pumping action of the heart fails and the blood pressure falls precipitously, producing a significant reduction in cerebral blood flow. Neurophysiological explanations suggest a hyper-sensitive vagal system with brain stem centres reacting excessively to painful or emotional stimuli. Cardiac inhibition and respiratory arrest then lead to apnoea, cerebral anoxia, and unconsciousness. Thus, in response to a provoking incident, the child ceases to breathe in expiration, develops cyanosis, experiences syncope. and becomes unconscious and apnoeic.

The electroencephalogram (EEG) ${ }^{4}$ during breath-holding shows no seizure discharges, but transitory slow waves may appear. In some children the spells may be followed by a decrease in voltage or flattening of the EEG. Occasionally, convulsive movements may occur, but without change in the EEG.

Common causes of post-operative apnoea include hyperventilation, inadequate reversal of muscle relaxants or narcotics, and hypothermia in infants. These aetiologies produce apnoea which persists at the end of the surgical procedure, although narcotic depression and hypothermia may produce recurring apnoea. Hyperventilation was excluded after return of spontaneous respiration. In our practice morphine 0.4 to $0.5 \mathrm{mg} / \mathrm{kg}$ used routinely for operations lasting over two hours has not produced respiratory depression or apnoea and brief ventilation with oxygen would not have been sufficient 
therapy if morphine was the cause. Hypothermia and hypovolaemia were not present in or applicable to this case. Recurarization without overdosage of relaxant and after adequate reversal of the block with neostigmine probably does not occur except when gallamine is used in patients with renal disease. ${ }^{5}$ This patient's apnoea would be limited to breath-holding or certain types of seizures, ${ }^{6}$ barring an unlikely stroke.

Though breath-holding is usually benign and well-tolerated, the hypoxia possible in the immediate post-operative period could further compromise cerebral and cardiac oxygenation. Supported ventilation with oxygen then becomes specific therapy. Attempts at further therapy for reversal of the narcotic or muscle relaxant would be inappropriate and could complicate management.

\section{SUMMARY}

After recovery from anaesthesia for a urological procedure a two-and-a-half-year-old child with a history of breath-holding spells became apnoeic and cyanotic in the immediate post-operative period. The pathophysiology of breath-holding as the cause of the apnoea is discussed. Management includes ventilation with oxygen and avoidance of inappropriate treatment with drugs to reverse muscle relaxants or narcotic anesthetics.

\section{RÉȘUMÉ}

Le spasme du sanglot classique est un épisode d'apnée non épileptique avec perte de cons- cience, déclenché par la crainte, la rage, les pleurs, la douleur ou la frustration, et survenant surtout chez l'enfant de moins de six ans.

Un enfant de deux ans et demi avec une histoire de spasme du sanglot a présenté un épisode d'apnée et de cyanose après éveil d'une anesthésie. Une ventilation de courte durée à l'oxygène a été la seule thérapie nécessaire.

Une revue de la littérature récente ne mentionne pas cette entité comme cause d'apnée post-opératoire. La pathophysiologie du spasme du sanglot ainsi que le diagnostic différentiel de l'apnée post-opératoire sont discutés.

\section{REFERENCES}

1. Gastaut, H. \& Broughton, R. Epileptic seizures. Springfield: Thomas, p. 203 (1973).

2. LENNOX, W.G. Epilepsy and related disorders. (Vol. 1), Boston: Little, Brown \& Co., pp. 389-392 (1960).

3. Millichap, J.G. Paroxysmal disorders of the central nervous system. The Biologic Basis of Pedialtric Practice. Edited by R.E. Cooke. New York: McGraw-Hill, pp. 1281-1282: 1578 (1968).

4. Gibss, F.A. \& Gibas, E.L. Atlas of electroencephalography (Vol. 3). Redding, Mass.: Addison Wesley, p. 138 (1964).

5. WALTS. J.F., ThORPE, W.K., \& DILlon, J.B., Recurarization - fact or fiction? Anesth. Analg. 50: 879-885 (1971).

6. HubaerT, C.H. Covert seizures as a cause of post-operative apnea. Anesth. Analg. In press. 